\title{
Organizational and Economic Problems of Technical Development of the Russian Engineering
}

\author{
A. V. Streltsov ${ }^{1}$ \\ B. Y. Tatarskih ${ }^{1}$ \\ G. I. Yakovlev ${ }^{1}$ \\ 1. Samara State University of Economics, Russia, 443090, Samara, Sovetskoi Armii Street, 141; Correspondence: Samara State \\ University of Economics, 443090, Russia, Samara, Sovetskoi Armii Street, 141, Email: oisrpp@mail.ru
}

\section{Doi:10.5901/mjss.2015.v6n6s3p509}

\section{Abstract}

The paper discusses the problems of development in the Russian machine-building industry, studies its conditions, marks modern features that determine effectiveness of the industry, analyzes the characteristics of innovation and technical capacity changes at machine-building enterprises. The paper reveals the essence and characteristics of innovative renewal forms of fixed capital at machine-building enterprises, analyzes the role of implementation of large complex projects in development of the Russian machine-building industry and conditions of their formation. The authors propose organizational and economic directions of innovative renewal of fixed capital at Russian machine-building enterprises and ways to improve the efficiency of their development. The paper represents possibilities for joint ventures and international strategic alliances as promising forms of mutually beneficial cooperation in order to implement large-scale industrial projects and high-tech development of the Russian machine-building industry.

Keywords: problems of engineering, fixed capital, the degree of wear, restructuring, competitiveness, innovation, investment, strategic alliances, markets.

\section{Introduction}

Today mechanical engineering takes a special place in the industry of any developed country. In Russia machine-building enterprises are the traditional backbone of the industrial complex, the main factor in development of material and technical base of the economy. At the same time, their current status does not meet modern requirements, the pace of introduction and development of new technologies has slowed, and the level of competitiveness of a wide range of products is not high.

\section{Method}

The study of organizational and economic problems of development in the Russian machine-building industry is advantageously carried out in the following way.

It is necessary to study the features of machine-building enterprises, including the specific effects of historical development characteristics, assessment of significance in the Russian economy, trends in development of mechanical engineering in the years of market reforms, and others, since they largely determine the nature of accumulated problems and at the same time show possible directions of their solutions.

The most important step in this research is development of organizational and economic directions at Russian machine-building enterprises, the choice of these priorities, which are able to increase innovative activity, competitiveness of products and, ultimately, the efficiency of these enterprises.

It is advisable to identify the so-called "development tools" that can significantly improve the quality characteristics of Russian machine-building enterprises, especially the quality of the capital stock and output, as equipment creates the material and technical basis of enterprise functioning on relatively long-term, and competitiveness of manufactured goods determines its position in the market.

A significant element of the study should also be the definition of a new institutional framework necessary for implementation of the identified areas of development at Russian machine-building enterprises, from the perspectives of international scientific and industrial cooperation. 


\section{Results}

\subsection{Conditions of engineering}

Mechanical engineering takes an important place in the industrial complex of Russia. It is determined that machinebuilding enterprises produce a significant portion of the instruments of labor, provide production of consumer goods, employ a large number of employees. However, now its conditions are unstable, there are serious challenges to its sustainable development.

This tendency can be considered using an example of machine-economic activities of the Samara region, in which engineering has historically occupied a leading position in the industrial complex of the region (see Table 1).

Table 1. Production indices by economic activity of the Samara region (as a percentage of the previous year)

\begin{tabular}{|l|c|c|c|c|c|c|c|}
\hline Economic activities & $\mathbf{2 0 0 7}$ & $\mathbf{2 0 0 8}$ & $\mathbf{2 0 0 9}$ & $\mathbf{2 0 1 0}$ & $\mathbf{2 0 1 1}$ & $\mathbf{2 0 1 2}$ & $\mathbf{2 0 1 3}$ \\
\hline $\begin{array}{l}\text { Mining and quarrying, manufacturing, production and distribution of electricity, gas and } \\
\text { water }\end{array}$ & 103,4 & 103,1 & 80,7 & 114,4 & 105,8 & 102,2 & 101,0 \\
\hline Manufacture of machinery and equipment & 73,5 & 96,7 & 68,5 & 116,8 & 103,3 & 104,0 & 93,8 \\
\hline Manufacture of electrical optical equipment & 115,5 & 97,5 & 68,4 & 125,4 & 112,5 & 99,3 & 86,6 \\
\hline Manufacture of motor vehicles and transport equipment & 100,7 & 108,3 & 41,1 & 173,8 & 111,3 & 100,1 & 90,0 \\
\hline
\end{tabular}

It may be noted from the Table that according to economic activities that are associated with production of machinery and equipment manufacturing, the variability index was much higher and deeper than a decline in production in 2009. In 2013 the use of average annual production capacity of bearings was $33.3 \%$, machine tools - $29.1 \%$ (2012), electric transformers $-42.8 \%$, cars $-67.7 \%$.

Depreciation of fixed assets on production of machinery and equipment was $-39.7 \%$ at the end of 2013 , production of electrical equipment - 50.8\%, production of vehicles and equipment - 67.1\% (Samara Statistical Yearbook, 2014). These figures allow us to conclude that without solving the existing problems with the unsatisfactory condition of fixed assets, it is hardly possible to ensure stable, sustainable engineering development. Therefore, the need for careful study of existing problems and profound study of a set of measures to address them.

\section{Features of the Russian Machine-building Industry}

Features of the Russian machine-building industry can be classified into the following main features: the importance in the country's economy, according to specifics of the process, historical features of development, characteristics, formed as a result of market reforms.

From the point of view of significance in the Russian economy, machine-building enterprises are the basic material and technical elements. They are characterized by a high concentration of production. Mechanical engineering is a complex industry, whose products are designed for all sectors of the economy: industrial and non-consumption of consumer goods and funds to defend the state (WEBER, ALFEN 2010). Machine-building enterprises, producing instruments of labor, largely determine the achieved level of innovative potential in Russia.

The authors consider the fact that large machine-building complexes, since their formation, have been "townforming." Therefore, sustainable development in the Russian machine-building industry is necessary and solves many social problems associated with employment and living standards.

In specifics of the process there are the following features that define the shape of the modern Russian engineering. At any large and medium machine-building enterprise technological processes differ significantly from each other, but in the end they are combined in one assembly production (enterprise). Therefore, the successful activity of the machine-building assembly plant is affected by a number of factors related to interaction of divisions and companies suppliers. At the same time the specialization factor of enterprises - suppliers is a source of risk for them - they can become bankrupt in case if the assembly plant refuses to accept their products (raw materials, components in the finished product). However, we must bear in mind that the processes of reform, decentralization and privatization in the economy, firstly violated manageability of the Russian machine-building complex (there is no end-to-end interaction in a single process chain), and secondly, machine-building enterprises weakened because they were forced to compete directly with foreign firms - manufacturers of similar equipment even in the domestic market (more technologically advanced and integrated organizations, which is particularly important in the context of globalization and the WTO) (Yakovlev 2002). 
Considering the impact of historical features of development it may be noted that since inception of the Russian machine-building industry, its enterprises were formed as its highly technological processes: casting, forging, pressing production, mechanical, chemical, thermal, electro-physical handling, assembly stage, paint lines, production infrastructure (repair , tool management, communications, transportation, and others.). In addition, every such large and medium enterprise - complex had economic and technological infrastructure, which included the design and technological services, pilot production, commercial, financial and other departments, including housing and household services and departments on its own training. Therefore, the initial element of any change of fixed capital at enterprise-complexes is restructuring and separation of critical, in terms of profit, stages of the process chain and concentration of limited financial resources, mainly at these stages.

Throughout the Soviet period, it turned out that a large proportion of large and medium-sized machine-building enterprises was specialized, though not entirely, but in equipment and technology, in production of defense products. The other part of the civil resources was financed by a residual principle, whereby the fixed assets in that part turned out to be mentally worn out and not competitive (Tikhonov, 1981).

During the years of market reforms there were certain characteristics of modern Russian machine-building enterprises. We may note a slowdown in production of electronic and technical equipment, the level of competitiveness of high-tech products does not increase when there is insufficient labor, insufficient investment and infrastructural support, insufficient pace of research and development work.

In mechanical engineering in the last 20-25 years this research was 5-7 times less financed than in 1984-1990. While the share of spending on scientific research and marketing, development work is growing very slowly, this hinders the creation of scientific and technological potential and releasing of a new product.

The negative impact of technological multiculturalism factors increases in Russian engineering. Particularly difficult situation is in the blank production businesses, where the pace of technological development, laid down in the Soviet era, is still low. In engineering there is still no support programs for industrial research institutes and material-technical base of pilot production, with a high proportion of production of structurally complex high-tech products; the problem of matching the regulatory legal acts regulating and promoting scientific and technical activities is being solved slowly.

\subsection{Organizational and economic development in the Russian machine-building industry}

It is possible to decide the major organizational and economic problems of technical development in the Russian machine-building industry, through adjustment of the existing management development system in the machine-building complex. In this case, it should be noted immediately that it comes to managing in a market economic model, using indicative planning and entrepreneurial freedom of market legal entities. The content of specific elements and stages of the management system must comply with the standard theory of management and include goal setting, planning, organization, management, control (Malmberg, Maskell 2010). In addition, at each stage of the system it is necessary to solve a number of interrelated issues at the same time: technical, economic, social, organizational, and others.

To solve the technical problems it is necessary to stimulate the transition to an innovative form of renewal of fixed capital at enterprises in the basis of the control development system in the Russian machine-building complex. It should allow not only radically transforming equipment at enterprises, but also carrying out related changes in products, technologies, organization of production.

The solution of economic problems requires a search for concentration of investment resources in today's unstable economic environment, the focus on market research, improvement of the efficiency of the investment project (Schiller, 2012).

In order to solve the social and organizational issues it is necessary to rebuild the system of training for machinebuilding enterprises, especially in the blue-collar occupations, to create cross-cutting scientific and technical centers, which could, concentrating research, human resources and investment resources, carry out cross-industry research and development - design work based on needs of specific leading machine-building enterprises (for example: automotive, aircraft, machine tools, etc.), to improve information provision and others.

However, the solution of all these problems should be based on conversion of capital machinery enterprises, transition to the innovative form of their updates.

\subsection{The nature and characteristics of innovative renewal forms of fixed capital at machine-building enterprises}

Innovative renewal form of fixed capital at machine-building enterprises is complex transformation of all elements of business: products, technology, equipment, raw materials, production organization. Moreover, in contrast to the traditional 
form of replacement and renovation of work equipment, in the innovative one the first place is taken by changes in the product range and technology and only then by used equipment.

It determines the specific characteristics of innovative renewal forms of fixed capital:

- Changes in technology and equipment to meet the needs of a market perspective, while traditional upgrade involves converting the means of labor within the framework of existing problem solution;

- Higher investment capacity than in the traditional form, as it involves solution of a set of interrelated problems;

- Continuous, time-limited implementation, and the traditional form has an ongoing, permanent nature;

- Higher risk, because orientation on the future increases uncertainty in economic calculations regarding the exact estimation of parameters in the target market of a new product, possible mistakes in its definition lead to much greater losses - due to higher capital intensity of the innovative form compared with the traditional one (BOUSSABAINE, KIRKHAM, 2005).

Therefore, choosing the way how to implement innovative renewal forms of fixed capital at Russian machinebuilding enterprises, it is necessary to take into account these characteristics (unpredictability, risk, high capital intensity, speed of implementation, etc.) (Esko 2012).

\subsection{Formation of complex development projects in the Russian machine-building industry}

To implement innovative renewal of fixed capital at Russian machine-building enterprises it is necessary to select an instrument of its implementation, which will ensure all of its advantages and, at the same time, will take into account all of its special characteristics. As such a tool, in our opinion, it is better to use formation and implementation of large complex development projects at machine-building enterprises. At the heart of each of these projects there is identification of promising market demand for products, formation of design and technological documentation for its production. As promising products you should select complex high-tech products, allowing you not only to provide a competitive advantage in company's functioning in the future, but also to ensure modernization and growth of production at Russian allied enterprises.

Launch of prospective, competitive products will also increase the load of existing production facilities. This will boost the price competitiveness of products which are already produced by reducing the share of fixed costs in their cost. Thus, introduction of long-term, competitive products in production creates a kind of synergistic effect; thereby it increases the efficiency of the entire enterprise. It should also be borne in mind that the use of Russian allied enterprises will reduce the risks of the project and increase the scale of hardware upgrades in the entire process chain. These large development projects on production of perspective, complex, high-tech products can be defined as integrated development projects at Russian machine-building enterprises, which, having a relatively high "investment attractiveness", can be the basis of commercial and technological development of production, involving resources of other participants in the innovative process of creating new engineering products.

However, formation of such complex projects must comply with certain conditions.

First, products, manufactured as a result of high technology projects, must be produced with the use of advanced technologies, hold leading positions in the Russian market of such products, and their considerable part have to be exported.

Second, the amount of total investments in the technological production chain of new products should be more than the amount of investments in the final assembly plant.

Third, the project on launching a new product should provide localization of materials and components in the country in order to reduce costs.

Fourth, each integrated project on production of new products should be in a form of high-tech production, linked to priority areas of scientific and technological development of Russia or development and implementation of Russian federal target programs. This will allow the claim to state support and reduce the amount of costs to commercial organizations.

Fifth, production of sophisticated high-tech goods as part of a comprehensive project should be cheaper compared to competing designs.

Under these conditions implementation of complex projects is the most promising direction, which allows updating the fixed capital at Russian machine-building enterprises, improving the efficiency of their operations and providing conditions for further industrial and technological development. 


\subsection{The concept of "strategic alliances" and joint ventures}

The initial stage in formation of a comprehensive project for any engineering enterprise should be the definition of complex high-tech products, competitive market, not only now, but in a long run. Development of such a product can be done in-house research and development departments or using ready products of more technically and technologically advanced companies on the basis of international technology transfer. The last option allows you to save time and costs (Yakovlev, Kosyakova 2014).

Thus, the priority forms of attracting investment and technology should be investments in certain commodity market niches as a result of interaction of specific enterprises (European Commission, 2005). The advantages of Russian machine-building enterprises in this collaboration may be the presence of existing industrial areas, existing infrastructure, a piece of equipment, qualified personnel, communication with suppliers and customers, work experience, large markets, geographical location and others.

It is possible to implement mutually beneficial cooperation using large machine-building enterprises, implementing existing in world practice of internationalization concept for production and organization of strategic alliances (Tatarkin, 2003). Thus, it should be noted that in fact, the use of these concepts in Russia is not entirely new. Even in the USSR in 1923 there was awarded a mutually beneficial cooperation agreement between Leningrad trust of products with the French general wireless telegraphy company. By 1931, the number of such agreements was hundreds, including firms "Ford" (USA) concerning the automotive industry, "Krupp" (Germany) - production of special grades of steel and iron, AEG (Germany) - production of electrical equipment and others.

At present, the objectives of the international alliance (BRANSFIELD, SCHLUETER, 2004) can be: an increase in market share or entering new markets, bringing of existing products to series production, joint research and development work, division of the market when entering new markets, innovation, and others.

For Russian machine-building enterprises in cooperation with a foreign company it is important to maintain their independence. It is possible to ensure it having joint entrepreneurial activities within the framework of the strategic alliance through the use of such organizational forms, such as joint ventures and consortia.

The joint venture is a form of economic cooperation between two or more independent from each other enterprises, it is reflected in the fact that legally independent company is founded or purchases together to perform tasks in the common interest of the founding companies.

Consortia - association of companies on a contract basis, created to perform specific, clearly defined tasks, after which it ceases to exist. The participants of consortia associations, while retaining their independence, follow the co-lead management only in that part of the activity which deals with the objectives of the consortium.

The use of these forms of organization, in which Russian companies retain their independence, will allow more reasonably qualifying for government support measures that will reduce the cost of implementing large, complex investment projects.

\section{Discussions}

In this paper the authors suggest organizational and economic directions in development at Russian machine-building enterprises, based on the need to update on the basis of their innovative core capital, implementation of large, complex, high-tech projects and cooperation with more technically and technologically advanced companies, including on the basis of international cooperation. The subject of discussion may be importance of benefit cooperation for foreign partnercompanies, the risk of such cooperation with Russian enterprises in modern conditions of unstable economic and political environment. The authors may also discuss the possibility to use the research results of companies in other industries and fields of activity.

\section{Conclusion}

The proposed organizational and economic directions in development of Russian machine-building enterprises will help provide a solution to the major problems of their operations in a market economic model, increase the efficiency of production. Using organizational forms of cooperation between economic entities on the basis of joint ventures and strategic alliances will promote the renewal of fixed capital and increase the competitiveness of products produced by Russian machine-building enterprises, and increase efficiency of partner companies. For them, the benefits of mutual cooperation can be manifested in entering new markets, reducing production costs, risks in product development and, ultimately, revenue growth and profitability of their activities. 


\section{References}

Samara Statistical Yearbook. Samara: Samarastat 2014.

Weber B., Alfen H.W. Infrastructure as an asset class: investment strategies, project finance and ppp. - John Wiley \& sons, $2010 .-284$ p.

Yakovlev, G.I. Problems in formation of market strategy at industrial enterprises in the open economic system. Foreign economic aspect (monograph). Saratov: Saratov State University, 2002, 156 p .: ill.

Tikhonov, N.A. The main directions of economic and social development of the USSR in $1981-1985$ and up to 1990 [Text]: N.A. Tikhonov's report -Chairman of the Council of Ministers of the USSR - to the Party Congress -27. 02.1981 Yakutsk: Yakutsk Publishing House, 1981, p. 52.

Malmberg, A., Maskell, P. An evolutionary approach to localized learning and spatial clustering // The Handbook of Evolutionary Economic Geography / Ed. By R. Boschma and R. Martin - Cheltenham, UK, Northampton, MA, USA: Edward Elgar Publishing, Inc., 2010, pp. 391-405.

Schiller, R. Irrational optimism as a market-driven, reckless behavior (Irrational Exuberance. Second Edition Revised \& Updated) .- M .: Alpina Publisher, 2013. - 422 p.

BOUSSABAINE A., KIRKHAM R. Whole life-cycle costing: risk and risk responses. Blackwell publishing ctroup, oxford, uk. 2005.

Esko, Aho. Innovation - a long game [electronic resource] // Sheets. 2012. № 204 (3218). Mode of access: Vedomosti.ru.

Yakovlev, G.I., Kosyakova, I.V. Features of realization of modern industrial agenda in the Russian context // Vestnik of Samara State University of Economics, 2014 №6 (116). S.84-88. 10.

Implementing the Community Lisbon Programme: A policy framework to strengthen EU manufacturing - towards a more integrated approach for industrial policy. - European Commission, 2005, COM (2005) 474 final.

Tatarkin, A.I. Keys to the world market [Text] / A.I. Tatarkin. MA: Economics, 2003.- 260 pp.

Bransfield S., Schlueter D. When joint ventures go bad // china business review Publisher: us china business council issn: $0163-7169$. volume: 31 issue: 5 Year: 2004 Pages: 24-27.

Leiponen A.E. Competing through cooperation: the organization of standard setting in wireless telecommunications // management science. 2008. vol. 54. no 11. p. 1904-1919. 